\title{
ENDOPHYTIC FUNGI FROM THE BRAZILIAN FLORA AND THEIR EMPLOYMENT IN BIOTRANSFORMATION REACTIONS
}

\author{
Valmore Henrique Pereira dos Santos ${ }^{\mathrm{a}}$ and Eliane de Oliveira Silva*a, $\mathbb{C}$ \\ Departamento de Química Orgânica, Instituto de Química, Universidade Federal da Bahia, 40170-115 Salvador - BA, Brasil
}

Recebido em 20/03/2019; aceito em 06/06/2019; publicado na web em 27/06/2019

\begin{abstract}
The biotransformation reactions are used as a successful alternative to derivatization by the traditional chemistry because they conduct to uncommon reactions, which would hardly be carried out by chemical synthesis. A wide diversity of compounds may be metabolized by fungi, leading to chemical derivatives through selective reactions that work under ecofriendly conditions. Endophytic fungi live in symbiosis with health tissues of plants. The employment of endophytic fungi as enzymatic sources to biotransformation reactions is very promising since these microorganisms came from uncommon and underexplored habitat. The environmental conditions directly influence the composition of the endophytic microbiota and its genetic expression, which could change also the production of the enzymes. The extraordinary richness of the Brazilian biodiversity is a key factor in the diversification of the endophytic community. The present review presents a mapping of the biotransformation reactions catalyzed by Brazilian endophytic fungi. Our findings contribute both to the appreciation of these fungi in the chemical derivatization and for the preservation of the Brazilian species.
\end{abstract}

Keywords: biotransformation; endophytic fungi; Brazilian biodiversity.

\section{INTRODUCTION}

Endophytic microorganisms are bacteria or fungi that live in symbiosis with health plant tissues. ${ }^{1}$ Endophytic microorganisms contribute to the natural defenses of host plants, preventing herbivory and invasion of pathogens. ${ }^{2,3}$ Generally, the endophytic fungi are transmitted horizontally between plants through spores or fragmentation of their hyphae, which are then spread by herbivores or abiotic agents such as wind or rain. ${ }^{4}$

The relationships between the host plant and its endophytic fungi have enormous ecological importance and they are mediated by secondary metabolism. ${ }^{5}$ Several studies on secondary metabolites isolated from endophytic fungi cultures, mainly those focused on biological activities and chemical diversity, have demonstrated the importance of these compounds for the development of new drugs. Within this context, an endophytic fungus isolated from American Daphnopsis produced the diterpene guanacastepene (Figure 1), active against both methicillin-resistant Staphylococcus aureus and vancomycin-resistant Enterococcus faecium strains. ${ }^{6}$ In addition, an endophytic fungus isolated from Quercus coccifera leaves produced the benzoquinone hinnuliquinone (Figure 1), which is a potent inhibitor of HIV virus protease. ${ }^{7}$ Some reports also highlight the occurrence of metabolic coincidences between the endophytic and its host plant, allowing the biosynthesis of same substance by both organisms. ${ }^{3}$

In addition to the importance of the secondary metabolism of endophytic fungi, the enzymatic potential of these microorganisms has also attracted the attention of several research groups. One of the major challenges of biocatalysis is the discovery and/or development of suitable systems for different applications. Filamentous fungi have a wide capacity in the production of several enzymes since they are capable of degrading several organic substances of the environment. ${ }^{8}$ The broad enzymatic arsenal of fungi can then be exploited by biotechnology, such as in biotransformation and bioremediation processes. Biotransformations can be defined as the use of biological systems to catalyze chemical changes in substances that do not

*e-mail: elianeos@ufba.br<smiles>CC(=O)OC1C(=O)C2=CC3=C(C=O)C(O)CC[C@]3(C)CCC2(C)C1C(C)C</smiles>

a

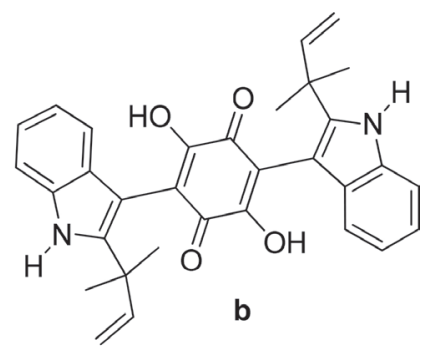

Figure 1. Chemical structures of the guanacastepene (a) and hinnuliquinone (b)

constitute their common substrates. ${ }^{9}$ A number of advantages can be mentioned for the use of fungi as catalysts of chemical reactions (in comparison with the traditional chemical catalysts), such as the possibilities of using neutral $\mathrm{pHs}$, mild temperatures and pressures, decrease in expenses with organic solvents, along with the occurrence of reactions regio-, chemo- and stereoselective. ${ }^{10,11}$ Despite some limitations, mainly related to the toxicities of some substrates and products to the fungal cell, biotransformations continue to play a key role in the development of new approaches to chemical derivatization.

The recognized potential of the endophytic microbiota in the degradation of several xenobiotics has contributed to the appreciation of endophytic microorganisms in biotransformation processes. ${ }^{12}$ The endophytic fungi are able to produce several types of enzymes that allow the colonization of the host plant. ${ }^{13}$ These microorganisms are then promising niches for the discovery of new biocatalyst. In addition, the host-endophytic coevolution favors the diversification of the endophytic enzymatic system, since the genes may be changed during the evolutionary steps. The search for new biocatalytic systems among endophytic communities can be guided by previous knowledge about the secondary metabolism of the host plant or by strategies employed during the isolation of such microorganisms. ${ }^{13}$ Endophytic microorganisms have developed adaptive strategies to deal with the chemical arsenal of the host plant. Some studies report that endophytic fungi are able to biotransforming secondary metabolites of their host plants for their own benefit. ${ }^{14,15}$ Thus, prior knowledge about the typical natural products of a plant will indicate 
the probable enzymatic specificity of its endophytes. In addition, the isolation of new endophytic for the biotransformation of a particular substrate can be done by incorporating such substrate to the culture media used in the microorganism isolation from the plant organs. This approach will provide the selection of resistant endophytic strains to that substrate of interest. ${ }^{13}$

Biotransformation processes may be employed in several approaches whose objectives are different. Biotransformations catalyzed by filamentous fungi are considered economically competitive technologies for the modification of chemicals, leading to structural diversification of drugs or other bioactive substances. ${ }^{16}$ The reactions catalyzed by filamentous fungi have a high degree of selectivity and attend to the Green Chemistry principles. When biotransformation reactions using fungi are employed in modifications of the chemical structures of natural products, limitations associated with the obtaining such substances on low yields can be circumvented. Chemical diversification mediated by biotransformations has provided interesting leads for the development of new drugs. ${ }^{17}$ In addition, the chemical reactions catalyzed by filamentous fungi are important for the prediction of metabolism that several xenobiotics could undergo after oral administration in humans. Since the seminal observations made by Smith e Rosazza, ${ }^{18}$ filamentous fungi are considered capable of metabolizing xenobiotics likewise the enzymes from the mammalian cytochrome P-450. Typical reactions of mammalian metabolism can be successfully mimicked by the fungal enzyme systems, such as functionalization (phase I) or conjugation (phase II) reactions.

Although the scientific literature has studies on chemical reactions catalyzed by isolated enzymes, the use of whole cells in these reactions show the best results. ${ }^{19}$ Most enzymes require specific cofactors, which are naturally available by living cells. The enormous enzymatic potential of filamentous fungi guarantees to these microorganisms a prominent place in biotransformation studies..$^{20}$

Within the context discussed above, the characterization of new enzymatic systems from less exploited habitats is a highly innovative area of multidisciplinary interest. The present review sought to systematize several studies of biotransformations carried out with endophytic fungi isolated from plant material collected in Brazil. Taking into account that the expression of the genetic code of endophytic fungi can be highly affected by the environment in which they develop, ${ }^{3,21,22}$ the endophytic from the Brazilian biodiversity could present exclusive enzymatic systems. The full knowledge and exploration of Brazilian biodiversity will only be possible through sustainable technological development, which can be achieved through the use of diverse biotechnology approaches. ${ }^{23}$ The following observations will certainly contribute to the dissemination of knowledge about the enormous enzymatic potential of Brazilian endophytic fungi, which will guide future scientific studies and will contribute to the awareness of the need to preserve the Brazilian biodiversity.

\section{BIOTRANSFORMATION REACTIONS CATALYZED BY BRAZILIAN ENDOPHYTIC FUNGI}

Microbial transformations are enzymatic reactions that use the metabolic activities of microorganisms to modify chemical structures of substrates. The use of whole microbial cells in such reactions, especially those in culture media, is a more economically feasible process than the use of isolated enzymes. The enzymes inside the cells are stable and their cofactors are naturally regenerated. In this way, filamentous fungi have been the most frequently studied cellular systems for biotransformation reactions. ${ }^{24}$ The high specificity observed in the enzymatic reactions is attractive especially when considering the low rate of stereoselectivity seen in traditional organic chemical reactions. Several types of reactions can be catalyzed by filamentous fungi. For this reason, they are promising sources for the development of new biocatalysts, mainly to obtain chiral substances and for the functionalization of deactivated carbons.

The choice of enzyme source that will be employed is crucial for the success of biotransformation. It is worth mentioning that researches on the enzymatic systems of fungi from less exploited habitats favor the development of new catalytic systems to provide new chemical reactions. Plants are well known to harbor a manifold of secondary metabolites, which are chemical weapons to deal with predators. Endophytic microorganisms had to adapt themselves in order to cope with this chemical arsenal, and consequently they have developed enzymatic ways to convert or degrade the toxic compounds. ${ }^{13}$ This characteristic of endophytic microorganisms indicates that they could produce several interesting enzyme activities awaiting discovery.

Recently it has been reported that the composition of the endophytic microbiota of a given host plant differs significantly between different geographic areas. The different environmental conditions act as true "ecological filters" in the selection of endophytic strains that best adapt to the local conditions..$^{22}$ The following text presents a mapping of the chemical reactions catalyzed by the diversity of endophytic fungi isolated from Brazilian plants. Biotransformation reactions have been reported to (i) the achievement of chiral products with high enantiomeric excesses; (ii) the derivatization of natural products scaffolds to optimize their bioactivities; and (iii) the study of the in vitro metabolism of different drugs. The dissemination of different biotransformation studies using Brazilian endophytic fungi will contribute to the promotion of the use of these innovative enzymatic sources.

During the metabolism, the drugs are modified by the action of enzymes, conducting to more polar compounds that are more easily excreted from organisms. In humans, the neuroleptic phenothiazine drug thioridazine (1, Figure 2 ) is extensively metabolized by the isoenzymes contained in cytochrome P-450 system of the liver, by means of 5-sulfoxidation, $\mathrm{N}$-demethylation, mono-2- and di-2-sulfoxidation. The drug $\mathbf{1}$ is indicated for the treatment of schizophrenia and other psychiatric disorders. Although antipsychotic effects are attributed primarily to the $R$-enantiomer, thioridazine is marketed as a racemate. Based on the pharmaceutical importance of $\mathbf{1}$, its biotransformation was investigated using 12 endophytic fungi. Phomopsis sp. (TD2), Glomerella cingulata (VA1), Diaporthe phaseolorum (VR4), and Aspergillus fumigatus (VR12) were selected after the initial screening because of the evident stereoselectivities in the biotransformation of $\mathbf{1}$. The fungal biotransformation of $\mathbf{1}$ led to the oxidation of both side chain and phenothiazine ring sulfurs, resulting in the major human metabolites thioridazine-2-sulfoxide (1a) and thioridazine 5-sulfone (1b). Interestingly, both enantiomers of thioridazine (1) were metabolized by the fungi; however, 2-sulfoxidation yielded the $R$ configuration on the sulfur atom. ${ }^{25}$ The results of such study highlight that the biotransformation by endophytic fungi is a successful way to achieve chiral drugs with enantioselective preference.

Similar studies to those carried out with $\mathbf{1}$ were also developed with other chiral drugs. Miodrin (2, Figure 2) is an $\alpha$-adrenergic agonist indicated for the treatment of orthostatic hypotension. Miodrin (2) is administered as a racemic prodrug and its activation occurs after metabolization into desglimidodrine (2a). Stereoselective biotransformation of midodrine (2) to desglimidodrine (2a) by the endophyte Phomopsis sp. (TD2) was evaluated by capillary electrophoresis, which was able to simultaneously detect $\mathbf{2}$ and $\mathbf{2 a}$ in the culture medium used in the biotransformation. Phomopsis sp. (TD2) biotransformed $1.1 \%$ of (-)-midodrine to (-)-desiglimidodrine and $6.1 \%(+)$-midodrine to (+)-desglimidodrine. ${ }^{26}$ 
<smiles>C[Si]c1ccc2c(c1)N(CCC1CCCCN1C)c1ccccc1[Se]#S2</smiles>

1<smiles>CN1CCCCC1CCN1c2cc([Si](C)=O)ccc2C#[Si]c2ccccc21</smiles>

$1 \mathrm{a}$<smiles>C#[As]c1ccc2c(c1)N(CCC1CCCCN1C)c1ccccc1S2(=O)=O</smiles>

$1 b$<smiles>CN1CCCCC1CCN1c2cc(S(C)(=S)=S)ccc2C=[SH](=O)c2ccccc21</smiles>

$1 c$<smiles>COc1ccc(OC)c(C(O)CNC(=O)CN)c1</smiles>

2<smiles>CC(C)NCC(O)COc1cccc2ccccc12</smiles>

3<smiles>CC(C)Cc1ccc(C(C)C(=O)O)cc1</smiles>

4<smiles>COc1ccc(OC)c(C(O)CN)c1</smiles>

2a<smiles>CC(C)NC[C@H](O)COc1ccc(O)c2ccccc12</smiles><smiles>C[C@H](C(=O)O)c1ccc(CC(C)(C)O)cc1</smiles>

$4 a$<smiles>COC1=C(S(=O)Cc2nc3ccc(OC)cc3[nH]2)Nc2c(nc(S(=O)Cc3ncc(C)c(OC)c3C)nc2S(=O)Cc2ncc(CO)c(OC)c2C)C=C1</smiles><smiles>CCCSc1ccc2[nH]c(NC(=O)OC)nc2c1</smiles><smiles>CCCS(=O)c1ccc2[nH]c(NC(=O)OC)nc2c1</smiles>

$6 a$

Figure 2. Substrates (1-6) used in stereoselective biotransformations by Brazilian endophytic fungi and their derivatives

Some studies have reported that distinct endophytic fungi may be used for specific stereoselective reactions, which are useful to provide chiral chemical standards for analytical development. As part of the program focused on the study of stereoselective biotransformation of drugs, an analytical method was developed for the stereoselective analysis of two diastereoisomeric metabolites (1a and 1c) of the thioridazine (1, Figure 2) racemate. Both metabolites were obtained through the biotransformation of $\mathbf{1}$ by endophytic fungi isolated from Tithonia diversifolia. Among the evaluated endophytic fungi, four of them were distinguished by stereoselective biotransformation of 1: Phomopsis sp. (TD2), Diaporthe phaseolorum (VR4) and
Aspergillus fumigatus (VR12) mainly catalyzed mono-2-sulfoxidation and conducted to metabolite 1a; while Glomerella cingulata (VA1) mainly led to mono-5-sulfoxidation (metabolite 1c). ${ }^{27}$

Borges and co-workers employed capillary electrophoresis for the enantioselective analysis of propranolol (3, Figure 2) and 4-hydroxypropanolol. Propranolol (3) is a $\beta$-blocking agent indicated for the treatment of certain cardiovascular disorders. Both enantiomers of $\mathbf{3}$ exhibit biological activities, but the (-)-S-propranolol isomer is 100 times more active than $(+)-R$-propranolol. During biotransformation of $\mathbf{3}$ by mammalian enzymes, $\mathbf{3}$ is primarily hydroxylated at the 4-position of the naphthalene ring yielding the 
4-hydroxypropanolol. Screening of five endophytic fungal strains was performed and demonstrated that all were able to mimic the mammalian biotransformation of 3. Specifically, Glomerella cingulata (VA1) biotransformed $47.8 \%$ of $(S)$-(-)-propranolol to (S)-(-)-4-OH-propranolol (3a) after 72 hours of incubation, without the formation of the $(R)-(+)-4-\mathrm{OH}-$ propranolol enantiomer. ${ }^{28}$

Ibuprofen (4, Figure 2) is a non-steroidal anti-inflammatory drug containing an asymmetric $\alpha$-carboxylic carbon in the side chain. Although the anti-inflammatory activity has already been shown to be due exclusively to the (+)- $S$ enantiomer, ibuprofen (4) still is marketed in the racemic form. In humans, $\mathbf{4}$ is mainly metabolized to 2-hydroxy-ibuprofen and carboxy-ibuprofen, in addition to being conjugated with glucuronic acid (phase II metabolism). Based on this, an analytical method was developed for the simultaneous detection of ibuprofen (4), 2-hydroxy-ibuprofen and carboxy-ibuprofen in culture medium used in the biotransformation of $\mathbf{4}$. Among the six fungi studied, only Nigrospora sphaerica (SS67) and Chaetomium globosum (VR10) biotransformed $\mathbf{4}$ enantioselectively. The main product was the (+)-S-2-hydroxy-ibuprofen (4a), with an enantiomeric excess of $69.16 \% .^{29}$

An analytical method for the simultaneous detection of omeprazole (5, Figure 2) and its metabolites, 5-hydroxy-omeprazole (5a) and omeprazole sulfone (5b), was also developed. Some endophytic fungi isolated from Viguiera sp. showed the ability to biotransformation of $\mathbf{5}$ into 5a and 5b: Glomerella cingulata (VA1), Guignardia mangiferae (VA15), Penicillium crustosum (VR4), Chaetomium globosum (VR10) and Aspergillus fumigatus (VR12)..$^{30}$

The endophytic fungus Penicillium crustosum (VR4) also showed importance in providing chiral standards for analytical methods development. P. crustosum (VR4) was used in the enantioselective biotransformation of albendazole (6, Figure 2) into its active metabolite (-)-albendazole sulfoxide (6a). The product of the biotransformation was extracted by liquid phase microextraction and analyzed by capillary electrophoresis, which demonstrated an enantiomeric excess of $50.4 \%$ for the formation of the metabolite $\mathbf{6 a}$. Moreover, the biotransformation of $\mathbf{6}$ by the endophytic fungus P. crustosum (VR4) occurred in the same way that the human metabolism. ${ }^{31}$

Because of safety, therapeutic and regulatory concerns, there has been an increasing interest in the development of processes capable of producing enantiomerically pure drugs. In this sense, one of the most important reactions in organic synthesis is the asymmetric reduction of prochiral ketones to produce optically pure alcohols, which are useful for the synthesis of bioactive compounds. The endophytic fungi Colletotrichum crassipes and Xylaria sp. were employed in a screening of biocatalysts useful for the stereoselective reduction of carbonyl compounds. The biotransformation of acetophenone (7, Figure 3) by $C$. crassipes yielded mainly (R)-1-phenylethanol (7a), after five days of incubation. When the biotransformation of 7 by $C$. crassipes was carried out for 10 days, the main metabolite detected was $(S)$-1-phenylethane-1,2-diol (7c). On the other hand, the biotransformation of acetophenone (7) by Xylaria sp. generated (S)-1-phenylethanol (7b). When 4-ethylcyclohexanone (8, Figure 3) was used as substrate, C. crassipes yielded the products trans-4-ethylcyclohexanol (8a) and cis-4-(1-hydroxyethyl) cyclohexanol (8b), after five days of incubation. The same fungus converted $\mathbf{8}$ into 4 -(1S-hydroxyethyl) cyclohexanone $(\mathbf{8 c})$, after 10 days of incubation. The biotransformation of $\mathbf{8}$ by Xylaria sp. yielded the metabolites 4-ethyl-4-hydroxycyclohexanone (8d) and 4-(1R-hydroxyethyl) cyclohexanone $(\mathbf{8 e})$, after 10 days of incubation. ${ }^{32}$

The optically pure chiral amines are also important starting materials for organic synthesis. Among the methods for obtaining such amines, the use of $\omega$-transaminase in biocatalytic processes has emerged as promising strategy. Twenty endophytic fungi were evaluated for $\omega$-transaminase activity, by means of the kinetic resolution of rac-1-phenylethylamine (9, Figure 3). The endophyte Stemphylium lycopersici was selected as the best biocatalyst since it was responsible for the kinetic resolution of substrate 9 leading to $99 \%$ enantiomeric excess for the (R)-1-phenylethylamine enantiomer (9a). When the biotransformation was investigated using sterically hindered racemic amines as substrates, $r a c$-1,2,3,4-tetrahydro-1-naphthylamine (10, Figure 3) and rac-phenylbutylamine (11, Figure 3) were also satisfactorily resolved. The latter biotransformations yielded the metabolites $(R)$-1,2,3,4-tetrahydro-1-naphthylamine (10a) and $(R)$-1-phenylbutylamine (11a), respectively, with up to $91 \%$ of enantiomeric excesses. ${ }^{33}$

In addition to the stereoselective aforementioned conversions, other biotransformation approaches using endophytic microorganisms could be developed since the fungal enzymes are widely known for their ability to synthesize complex molecules and degrade toxic substances. In particular, some studies with Brazilian endophytic fungi have dedicated to the detection of specific enzymes. Several endophytic fungi isolated from Brazilian Cerrado plant species were evaluated for esterase production. The substrates used in such screening were ethyl butanoate (12, Figure 4), ethyl acetate (13, Figure 4) and methyl propanoate (14, Figure 4). All substrates were hydrolyzed by endophytic fungi extracellular enzymes (EC 3.1.1.1 carboxylesterases) to the respective butanoic (12a), acetic (13a) and propanoic (14a) acids. The best results regarding esterase production were obtained with the fungus Periconia atropurpurea (XIA-04), which showed interesting esterase activity in short chain esters. ${ }^{34}$

The production of monoxygenases by the endophytic fungus Penicillium brasilianum isolated from Melia azedarach was investigated by using the substrate 1-indanone (15, Figure 4). As result of the biotransformation of $\mathbf{1 5}$ by $P$. brasilianum, di-idrocoumarin (15a) and $(R)$-(-)-3-hydroxy-1-indanone (15b) were isolated with an enantiomeric excess of $78 \%$. Conversion of $\mathbf{1 5}$ to $\mathbf{1 5 a}$ characterized the ability of $P$. brasilianum to catalyze Baeyer-Villiger type reactions by oxidizing the cyclic ketone to the corresponding lactone. The oxidants typically employed by the synthetic approaches in the Baeyer-Villiger reactions present high toxicity, which values the enzymatic use for this purpose. ${ }^{35}$

The biotransformation reactions by filamentous fungi have demonstrated important results in the derivatization of bioactive compounds. Within this context, the Brazilian endophytic fungi have provided interesting reactions in these substrates, as shown below.

The biotransformation of the tetrahydrofuran lignan (-)-grandisin (16, Figure 5) by the endophytic fungus Phomopsis sp., isolated from Viguiera arenaria, led to the formation of the metabolite 3,4-dimethyl2-(4'-hydroxy-3',5'-dimethoxyphenyl)-5-methoxytetrahydrofuran (16a). It has been proposed that the aliphatic methoxyl group of the compound 16a must have been initially generated by oxidation at the C-5 position, followed by rearrangement to a lactone and displacement of the aromatic ring. Further reduction of the hemiketal and $O$-methylation of the hydroxyl group could explain how the fungus converted the 3,4,5-trimethyoxyphenyl group of $\mathbf{1 6}$ into the methoxy group of the metabolite 16a. In addition, the trypanocidal activities of (-)-grandisin (16) and its metabolite (16a) were evaluated and demonstrated to be quite similar. This finding highlights that the elimination of one of the 3,4,5-trimethoxyphenyl rings did not hinder trypanocidal activity, which may be important for the synthetic planning of new drug candidates. ${ }^{36}$

Penicillium griseoroseum was isolated as endophytic from Coffeea arabica seeds and then used in the biotransformation of 5,7,3,4,5-pentamethoxiflavanone (17, Figure 5). The fungus modified 
<smiles>CC(=O)c1ccccc1</smiles>

7<smiles>C[C@@H](O)c1ccccc1</smiles>

$7 a$<smiles>CC(O)c1ccccc1</smiles>

$7 b$<smiles>OC[C@@H](O)c1ccccc1</smiles>

$7 c$<smiles>CCC1CCC(=O)CC1</smiles>

8<smiles>CC[C@H]1CC[C@H](O)CC1</smiles>

$8 a$<smiles>CC(O)[C@H]1CC[C@@H](O)CC1</smiles>

$8 b$<smiles>C[C@H](O)C1CCC(=O)CC1</smiles>

$8 c$<smiles>C[C@H](O)C1CCC(=O)CC1</smiles>

8d<smiles>CCC1(O)CCC(=O)CC1</smiles>

$8 e$<smiles>CC(N)c1ccccc1</smiles>

9<smiles>NC1CCCc2ccccc21</smiles>

10<smiles>CCCC(N)c1ccccc1</smiles>

11<smiles>C[C](N)c1ccccc1</smiles>

$9 a$<smiles>N[C@H]1CCCc2ccccc21</smiles>

$10 \mathrm{a}$<smiles>CCC[C@H](N)c1ccccc1</smiles>

Figure 3. Substrates (7-11) used in biotransformations by Brazilian endophytic fungi and their chiral derivatives<smiles>[R]COC(=O)C[R]</smiles>

12: $\mathrm{R}^{1}=\mathrm{C}_{2} \mathrm{H}_{5} ; \mathrm{R}^{2}=\mathrm{CH}_{3}$

13: $R^{1}=H ; R^{2}=\mathrm{CH}_{3}$

14: $\mathrm{R}^{1}=\mathrm{CH}_{3} ; \mathrm{R}^{2}=\mathrm{H}$<smiles>[R]CC(=O)O</smiles>

12a: $R^{1}=\mathrm{C}_{2} \mathrm{H}_{5}$

13a: $R^{1}=H$

14a; $\mathrm{R}^{1}=\mathrm{CH}_{3}$<smiles>O=C1C2CCC1c1ccccc12</smiles>

15<smiles>O=C1CCc2ccccc2O1</smiles>

$15 \mathrm{a}$<smiles>O=C1C=Cc2ccccc2[C@H]1O</smiles>

$15 b$

Figure 4. Substrates (12-15) and their derivatives used in biotransformations by Brazilian endophytic fungi to the detection of specific enzymes

the position 6 of flavanone $\mathbf{1 7}$ through the insertion of the clavatol, a typical polyketide produced as a secondary fungal metabolite. The derivative was identified as a benzylated flavonoid (17a). The study demonstrated the presence of enzymes capable of catalyzing $\mathrm{C}-\mathrm{C}$ binding, which is uncommon in fungi. ${ }^{37}$

Chalcones have several interesting bioactivities and they are natural precursors of flavonoids. The endophytic fungus Aspergillus flavus isolated from Paspalum maritimum Trin. was used in the biotransformation of chalcone (18, Figure 5), 3,4,5-trimethoxychalcone (19, Figure 5), and 2,3,4,4' - tetramethoxychalcone (20, Figure 5). The products from the biotransformations were diidrochalcone (18a), 3,4,5-trimethoxyidrochalcone (19a), and 2,3,4,4'-tetramethoxyidiocolcholane (20a), respectively. A. flavus catalyzed the regioselective biorreduction of chalcones, since only the olefinic C-C double bonds were modified and no reaction occurred at the $\alpha, \beta$-unsaturated carbonyl double bond. ${ }^{38}$ 
The biotechnological potential of five endophytic fungi isolated from baru (Dipteryx alata Vog.) was reported. Preliminary results obtained in the biotransformation process showed that three strains bioconverted $\alpha$-pinene (21, Figure 5) into verbenol (21a) through hydroxylation of one of the carbons $\mathrm{sp}^{3}$ of the bicycle. ${ }^{39}$

The production of natural fragrances has high commercial value and terpenes play a central role in this topic. Limonene (22, Figure 5) is a cyclic monoterpene commonly found in citrus fruits. Aiming the bioaroma production, the endophytic fungus Phomopsis sp. isolated from Pinus taeda was used in the biotransformation of limonene (22). When the biotransformation was performed in culture medium containing glucose and (+)- $R$-limonene (22), several volatile

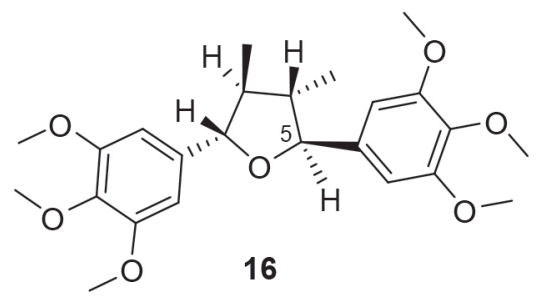<smiles>COc1cc(OC)c2c(c1)OC(c1cc(OC)c(OC)c(OC)c1)CC2=O</smiles><smiles>[Z1]c1ccc(C(=O)/C=C/c2cc([R])c([R])c([R])c2[R])cc1</smiles>

18: $R=R^{1}=R^{2}=R^{3}=R^{4}=H$

19: $R=R^{4}=H ; R^{1}=R^{2}=R^{3}=M e O$

20: $R=R^{1}=R^{2}=R^{4}=M e O ; R^{3}=H$<smiles>CC1=CCC2CC1(C)C2</smiles>

21<smiles>CC1=CCC(C(C)(C)O)CC1</smiles>

$22 a$<smiles>CC1=CCC(O)(C(C)C)CC1</smiles>

$22 b$<smiles>C=C(C)[C@H]1CC=C(C)C(=O)C1</smiles>

22c substances were detected by gas chromatography: $\alpha$-terpineol (22a), terpinen-4-ol (22b), $R$-carvone (22c), $1 S, 2 S, 4 R$-(+)-limonene-1,2diol (22d), trans-carveol (22e), and cis-carveol (22f). ${ }^{40}$

Piplartin (23, Figure 6) is an alkaloid found naturally in plants of the Piper genus and it has interesting anticancer activities. The biotransformation of piplartin (23) by the endophytic fungus Penicillium crustosum isolated from Viguiera robusta resulted in two metabolites: 3,4-di-idropiplartin (23a) and 8,9-di-idropiplartin (23b). Selective hydrogenations of the double bonds were observed, both those belonging to the heterocycle and the aliphatic chain. ${ }^{41}$

The antihypertensive drug hydralazine (24, Figure 6) was biotransformed by the endophytic fungus Fusarium oxysporum SS46<smiles>COc1cc(C2OC(OC)C(C)C2C)cc(OC)c1O</smiles><smiles>COc1cc2c(c(OC)c1Cc1c(O)c(C)cc(C(C)=O)c1O)C(=O)CC(c1cc(OC)c(OC)c(OC)c1)O2</smiles><smiles>[R]c1ccc(C(=O)CCc2cc([R])c([R])c([R])c2[R])cc1</smiles>

18a: $R=R^{1}=R^{2}=R^{3}=R^{4}=H$
19a: $R=R^{4}=H ; R^{1}=R^{2}=R^{3}=M e O$
20a: $R=R^{1}=R^{2}=R^{4}=M e O ; R^{3}=H$<smiles>CC1=CC(O)C2CC1C2(C)C</smiles>

21a 
<smiles>COc1cc(/C=C/C(=O)N2CCC=CC2=O)cc(OC)c1OC</smiles>

23<smiles>COc1cc(/C=C/C(=O)N2CCCCC2=O)cc(O)c1OC</smiles>

$23 a$<smiles>COc1cc(CCC(=O)N2CCC=CC2=O)cc(OC)c1OC</smiles>

$23 b$<smiles>NNc1nncc2ccccc12</smiles>

24<smiles>C=C[C@]1(C)C=C2CC[C@H]3[C@@H](C(=O)O)CCC[C@]3(C)[C@H]2CC1</smiles>

25<smiles>C=C[C@]1(C)C=C2[C@@H](O)C[C@H]3[C@@](C)(C(=O)O)CCC[C@]3(C)[C@H]2CC1</smiles>

$25 a$<smiles>Cc1nnc2c3ccccc3cnn12</smiles>

24a<smiles>C=C[C@]1(C)C=C2CC[C@H]3[C@@H](C(=O)O)CCC[C@]3(C)C2CC1</smiles>

26<smiles>C=C[C@]1(C)C=C2CC[C@H](C)[C@H](C(=O)O)C2=C[C@H](O)[C@@H]1C</smiles>

26a<smiles>C=C[C@]1(C)C=C2C(=O)C[C@H]3[C@@H](C(=O)O)CCC[C@]3(C)C2(O)CC1</smiles>

25b

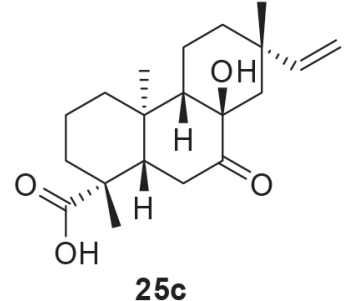

$25 c$

Figure 6. Bioactive compounds used as substrates (23-26) in biotransformations by Brazilian endophytic fungi and their derivatives

and yielded the 3-methyl-1,2,4-triazolo[3,4- $\alpha]$ phthalazine (24a). The mechanism of biotransformation of $\mathbf{2 4}$ to $\mathbf{2 4 a}$ was studied using labeled precursor $\left(1-{ }^{13} \mathrm{C}\right.$-D-glucose $)$ and revealed the incorporation of an acetyl-CoA unit, followed by cyclization. ${ }^{42}$

The diastereoisomeric diterpenes ent-pimara-8(14)-15-dien19-oic acid (25, Figure 6) and isopimara-8(14)-15-dien-18-oic acid (26, Figure 6) were distinctly functionalized by the endophytic fungus Preussia minima, isolated from Cupressus lusitanica. The biotransformation reactions consisted of oxidations at different positions of the diterpenes, depending on the substrate used. Thus, ent-pimara-8(14)-15-dien-19-oic acid (25) was biotransformed into 7 $\beta$-hydroxy-ent-pimara-8(14)-15-dien-19-oic acid (25a), 7-oxo-8 $\beta$ hydroxy-ent-pimara-8(14)-15-dien-19-oic acid (25b), and 7-oxo$9 \beta$-hydroxy-ent-pimara-8(14)-15-dien-19-oic acid (25c). On the other hand, isopimara-8(14)-15-dien-18-oic acid (26) was converted into $11 \alpha$-hydroxyisopimara-8(14)-15-dien-18-oic acid (26a), $7 \beta$-11 $\alpha$-dihydroxyisopimara-8(14)-15-dien-18-oic acid (26b), $1 \beta, 11 \alpha$-dihydroxyisopimara-8(14)-15-dien-18-oic acid (26c), and $7 \beta$-hydroxyisopimara-8(14)-15-dien-18-oic acid (26d). ${ }^{43}$

\section{CONCLUSION}

The use of biocatalysts conducts to selective and eco-friendly reactions. The development of new biocatalytic methods is still a growing area of interest for chemistry, microbiology and genetic engineering. Thus, the integration between biotransformation and organic synthesis may generate new synthetic strategies and the opening of new technological frontiers.

Indeed, the reactions of biotransformation catalyzed by Brazilian endophytic fungi are of great interest to the academic community, due to the stereospecific production of compounds of commercial interest, generation of high chemical diversity from known substrates, besides providing the study of the in vitro metabolism of various xenobiotics.

\section{ACKNOWLEDGEMENTS}

V. H. P. dos Santos thanks to Bahia Research Foundation (FAPESB) for his scholarship.

\section{REFERENCES}

1. Schulz, B.; Boyle, C.; Draeger, S.; Rommert, A. K.; Krohn, K.; Mycol. Res. 2002, 106, 996.

2. Demain, A. L.; J. Ind. Microbiol. Biotechnol. 2014, 41, 185.

3. Zhang, H. W.; Song, Y. C.; Tan, R. X.; Nat. Prod. Rep. 2006, 23, 753.

4. Saikkonen, K.; Wäli, P.; Helander, M.; Faeth, S. H.; Trends Plant Sci. 2004, 9, 275.

5. Strobel, G.; Daisy, B.; Microbiol. Mol. Biol. Rev. 2003, 67, 491.

6. Singh, M. P.; Janso, J. E.; Luckman, S. W.; Brady, S. F.; Clardy, J.; Greenstein, M.; Maiese, W. M.; J. Antibiot. 2000, 53, 256.

7. Singh, S. B.; Ondeyka, J. G.; Tsipouras, N.; Ruby, C.; Sardana, V.; Schulman, M.; Sanchez, M.; Pelaez, F.; Stahlhut, M. W.; Munshi, S.; 
Olsen, D. B.; Lingham, R. B.; Biochem. Biophys. Res. Commun. 2004, $324,108$.

8. Harms, H.; Schlosser, D.; Wick, L. Y.; Nat. Rev. Microbiol. 2011, 9, 177.

9. Hanson, J. R.; An introduction to biotransformations in organic chemistry; W. H. Freeman Spektrum: Oxford,1995.

10. Qi-He, C.; Jing, L.; Hai-Feng, Z.; Guo-Qing, H.; Ming-Liang, F.; Enzyme Microb. Technol. 2009, 45, 175.

11. Hai-Feng, Z.; Guo-Qing, H.; Jing, L.; Hui, R.; Qi-He, C.; Qiang, Z.; Jin-Ling, W.; Hong-Bo, Z.; Enzyme Microb. Technol. 2008, 43, 25.

12. St pniewska, Z.; Ku niar, A.; Appl. Microbiol. Biotechnol. 2013, 97, 9589.

13. Rodriguez, P.; Gonzalez, D.; Rodríguez Giordano, S.; J. Mol. Catal. B: Enzym. 2016, 133, S569.

14. Zikmundova, M.; Drandarov, K.; Bigler, L.; Hesse, M.; Werner, C.; Appl. Environ. Microbiol. 2002, 68, 4863.

15. Tian, Y.; Amand, S.; Buisson, D.; Kunz, C.; Hachette, F.; Dupont, J.; Nay, B.; Prado, S.; Phytochemistry 2014, 108, 95.

16. Silva, E. O.; Furtado, N. A. J. C.; Aleu, J.; Collado, I. G.; Phytochem. Rev. 2015, 14, 745 .

17. Kebamo, S.; Tesema, S.; J. Drug Metab. Toxicol. 2016, 6, 131.

18. Smith, R. V; Rosazza, J. P.; J. Pharm. Sci. 1975, 64, 1737.

19. de Carvalho, C. C. C. R.; Microb. Biotechnol. 2017, 10, 250.

20. Boaventura, M. A. D.; Lopes, R. F. A. P.; Takahashi, J. A.; Braz. J. Microbiol. 2004, 35, 345.

21. Tan, R. X.; Zou, W. X.; Nat. Prod. Rep. 2001, 18, 448.

22. Vaz, A. B. M.; Fonseca, P. L. C.; Badotti, F.; Skaltsas, D.; Tomé, L. M. R.; Silva, A. C.; Cunha, M. C.; Soares, M. A.; Santos, V. L.; Oliveira, G.; Chaverri, P.; Góes-Neto, A.; Sci. Rep. 2018, 8, 16151.

23. Da Gonçalves, C. C. S.; Marsaioli, A. J.; Quim. Nova 2013, 36, 1587.

24. Ma, L.; Liu, X.; Liang, J.; Zhang, Z.; World J. Microbiol. Biotechnol. 2011, 27, 2133.

25. Borges, K. B.; Borges, W. D. S.; Pupo, M. T.; Bonato, P. S.; Appl. Microbiol. Biotechnol. 2007, 77, 669.

26. Barth, T.; Pupo, M. T.; Borges, K. B.; Okano, L. T.; Bonato, P. S.; Electrophoresis 2010, 31, 1521.

27. Borges, K. B.; Borges, W. D. S.; Pupo, M. T.; Bonato, P. S.; J. Pharm. Biomed. Anal. 2008, 46, 945.
28. Borges, K. B.; Pupo, M. T.; Bonato, P. S.; Electrophoresis 2009, 30, 3910 .

29. Borges, K. B.; De Oliveira, A. R. M.; Barth, T.; Jabor, V. A. P.; Pupo, M. T.; Bonato, P. S.; Anal. Bioanal. Chem. 2011, 399, 915.

30. Borges, K. B.; Durán-Patrón, R.; José Sánchez, A. M.; Pupo, M. T.; Bonato, P. S.; Collado, I. G.; J. Braz. Chem. Soc. 2011, 22, 1140.

31. Carrão, D. B.; Borges, K. B.; Barth, T.; Pupo, M. T.; Bonato, P. S.; de Oliveira, A. R. M.; Electrophoresis 2011, 32, 2746.

32. Pinedo-Rivilla, C.; Cafêu, M. C.; Casatejada, J. A.; Araujo, Â. R.; Collado, I. G.; Tetrahedron: Asymmetry 2009, 20, 2666.

33. Queiroz, M. S. R.; Pinheiro, L. Z.; Sutili, F. K.; de Souza, P. M.; Seldin, L.; Muzitano, M. F.; de Souza, R. O. M. A.; Guimarães, D. O.; Leal, I. C. R.; J. Appl. Microbiol. 2018, 124, 1107

34. Lisboa, H. C. F.; Biasetto, C. R.; Medeiros, J. B. de; Araújo, Â. R.; Silva, D. H. S.; Teles, H. L.; Trevisan, H. C.; Braz. J. Microbiol. 2013, 44, 923.

35. Fill, T. P.; da Silva, J. V.; de Oliveira, K. T.; da Silva, B. F.; RodriguesFo, E.; J. Microbiol. Biotechnol. 2012, 22, 832.

36. Verza, M.; Arakawa, N. S.; Lopes, N. P.; Kato, M. J.; Pupo, M. T.; Said, S.; Carvalho, I.; J. Braz. Chem. Soc. 2009, 20, 195.

37. Da Silva, B. F.; Rodrigues-Fo, E.; J. Mol. Catal. B: Enzym. 2010, 67, 184.

38. Bitencourt, H. R.; Guilhon, G. M. S. P.; Arruda, M. S. P.; Marinho, A. M. R.; Santos, A. S.; Brasil, D. S. B.; Santos, L. S.; J. Braz. Chem. Soc. 2011, 22, 1333 .

39. Molina, G.; Pimentel, M. R.; Bertucci, T. C. P.; Pastore, G. M.; Chem. Eng. Trans. 2012, 27, 289.

40. Bier, M. C. J.; Medeiros, A. B. P.; Soccol, C. R.; Fungal Biol. 2017, 121, 137.

41. Silva-Junior, E. A.; Paludo, C. R.; Gouvea, D. R.; Kato, M. J.; Furtado, N. A. L. C.; Lopes, N. P.; Vessecchi, R.; Pupo, M. T.; J. Mass Spectrom. 2017, 52, 517.

42. Almeida, M. O.; Lopes, A. A.; Roberto, P. G.; Bertoni, B. W.; Pupo, M. T.; Phytochem. Lett. 2018, 26, 55.

43. Din, Z.; Medeiros, L. S.; Abreu, L. M.; Pfenning, L. H.; Jymeni, D. B. L.; Rodrigues-Filho, E.; Bioorg. Chem. 2018, 78, 436. 